\title{
Academy of Sciences of the U.S.S.R.
}

$\mathrm{T}$ HE election of members and member-correspondents of the Academy of Sciences of the U.S.S.R. took place in Moscow on January 28-29 at a general session of the Academy. Altogether fifty-six new academicians and a hundred and two member-correspondents were elected, the following being a list of those of scientific interest.

\section{Department of Technical Sciences}

Mechanics : Dr. N. I. Muskhelishvili, president of the Georgian Branch of the Academy of Sciences of the U.S.S.R., founder of a Soviet school in the theory of elasticity; Prof. N. E. Kochin (University of Moscow), a well-known authority on hydrodynamics ; Prof. E. A. Chudakov (Bauman Mechanico-Machine Building Institute, Moscow), author of numerous works on automobile engineering.

Mining: Prof. L. D. Sheviakov; Prof. A. P. German, an expert on mining mechanics.

Technical Physics : Dr. N. D. Papalexi, an authority on theoretical and experimental radio-engineering; Dr. M. V. Shuleikin, an authority on radio-communications ; Dr. V. P. Linnik, noted for his research in technical optics.

Energetics: Prof. M. V. Kirpichev (Molotov Institute of Energetics in Moscow), an authority on heat engineering; V. P. Nikitin, director of the Bauman Mechanico-Machine Building Institute of Moscow), an authority on electrical welding; Prof. V. S. Kulebakin (Zhukovsky Military Aviation Academy), known for his work on electro-technics.

Metallurgy : Dr. N. P. Chizhevsky, noted for his researches in the technology of metallurgical fuel; Prof. N. T. Gudtsov (Leningrad Industrial Institute), noted for his work on special steels.

Transport (hitherto not represented in the Department) : Dr. V. N. Obraztsov, an authority on the planning of railway stations and junctions; Dr. V.L. Posdiunin, known for his work on theoretical and practical questions relating to shipbuilding.

The following member-correspondents were also elected : G. V. Akimov, P. F. Antipin, I. I. Artobolevsky, I. M. Bakhurin, N. M. Beliayev, A. A. Bochvar, I. S. Bruk, N. G. Bruyevich, A. B. Chernyshev, D. M. Chizhikov, S. A. Christianovich, Z. F. Chukhanov, N. M. Gersevanov, A. V. Gorinov, A. S. Ilyichev, M. A. Kapeliushnikov, M. M. Karnaukhov, V. I. Kovalenkov, M. P. Kostenko, A. B. Lebedev, G. P. Peredery, A. S. Predvoditelev, L. N. Sretensky, S. S. Steinberg, M. A. Velikanov, V. P. Vologdin, I. N. Voznesensky, B. M. Vul and V. V. Zvonkov.

\section{Department of Mathematical and Natural SCIENCES}

Physico-Mathematical Sciences : Dr. S. L. Sobolev ; Dr. A. N. Kolmogorov; Prof. V. A. Fok (University of Leningrad) ; Dr. P. L. Kapitza, director of the Institute of Physical Problems of the Academy of Sciences ; G. A. Shain, astronomer at the Simeiz Observatory.

Chemistry: Prof. S. S. Nametkin (University of Moscow), author of a number of works on oils and synthetic aromatic substances; Dr. A. P. Orekhov, noted for his research in alkaloids; Prof. P. P. Shorigin (Stalin Industrial Academy), notedforhiswork on the creation of artificial fibres ; Dr. V. G. Khlopin, director of the Radium Institute of the Academy of Sciences; Dr. A. N. Terenin, noted for his research in the complex processes of photographic chemistry.

Geology and Geography: Dr. M. A. Usov, authority on the mineralogy of Western Siberia; Dr. P. I. Stepanov, authority on coal deposits of the U.S.S.R., particularly of the deposits in the Donets Basin; Dr. A. N. Zavaritsky, noted for his work on the ore deposits of the Urals; Dr. P. P. Shirshov, who took part in the North Polar Expedition on the drifting ice-floe of 1937-38 ; Dr. A. A. Grigorev, known for his work in physical geography.

Biology : Dr. T. D. Lysenko, noted for his work on vernalization; Dr. N. V. Tsitsin, known for his work in obtaining a hardy perennial wheat by crossing winter wheat with couch grass; Dr. L. S. Stern (the only woman academician elected), and Dr. I. S. Beritashvili, both noted for their original work in physiology; Dr. E. N. Pavlovsky, director of the Tajikistan base of the Academy of Sciences, noted for his research in applied zoology ; Dr. K. I. Skriabin, an outstanding authority on veterinary science.

Medicine (this is the first time that representatives of medicine have been elected to the Academy) : Drs. N. N. Burdenko, A. I. Abrikosov, M. I. Auerbach, N. N. Anichkov and A. D. Speransky.

Dr. Y. M. Shokalsky, known for his work in geography, was elected an honorary member of the Academy.

The following member-correspondents were also elected :

Physico-Mathematical Sciences : A. I. Alikhanov, V. A. Ambartsumian, S. I. Beliavsky, A. O. Gelfond, A. Y. Khinchin, A. A. Lebedev, M. A. Leontovich, L. S. Pontriagin, I. I. Privalov, D. V. Skobelstin.

Chemical Sciences: P. P. Budnikov, N. A. Izgarishev, A. F. Kapustinsky, I. A. Kazarnovsky, A.N. Nesmeyanov; N. I. Nikitin, V. M. Rodionov, S. Z. Roginsky, G. G. Urazov, S. I. Volfkovich.

Geologo-Geographical Sciences: N. N. Baransky, E. K. Fedorov, S. F. Fedorov, I. F. Grigoriev, F. N. Krasovsky, P. I. Lebedev, F. P. Savarensky, S. S. Smirnov, A. N. Tikhonov, A. G. Vologdin.

Biology : E. A. Asratian, V. P. Bushinsky, V. A. Dogel, A. A. Grossheim, K. S. Koshtoyants, A. I. Oparin.

Medicine: N. F. Gamaleya, N. I. Grashenkov, P. A. Herzen, M. B. Krol, B. I. Lavrentiev, V. P. Osipov, N. N. Petrov, O. N. Podvysotskaya.

Early in February, reorganization of the Academy of Sciences was discussed in connexion with the election of the large number of new academicians and member-correspondents enumerated above, as well as the substantial changes that have taken place in the structure of the Academy itself. As against the previous three departments-Department of Technical Sciences, Department of Mathematical and Natural Sciences, Department of Social Scienceseight departments are being formed, namely : Department of Physico-Mathematical Sciences, Department of Chemistry, Department of Geology and Geography, Department of Biology, Department of Technical Sciences, Department of History and Philosophy, Department of Economics and Law, Department of Languages and Literature. 